\title{
Personality Traits: Business versus Technical Graduates
}

\author{
Nurazariah Abidin and Salina Daud \\ College of Business Management and Accounting, Universiti Tenaga Nasional, Malaysia
}

\begin{abstract}
Effective interactions depend largely on personality traits, which is a consistent and longlasting tendency in behavior. In psychology, five major trait factors (Big Five personality traits) have been generally used to assess personality of people. The study highlights the practicality of importance-performance analysis as a means to assessing the importance of personality traits dimension that should be possessed by Malaysian graduates. The importanceperformance analysis is used to evaluate the gap in personality traits possessed by Business and Technical Graduates. The study is carried out in two phases: Phase 1 which involves a focus group session and Phase 2 which focus on establishing a questionnaire appropriate to the study across a diverse range of industries. The questionnaires were distributed to managers selected from a sampling frame. Graduates' personality attributes are analysed in terms of big five personality traits which include openness, conscientiousness, extroversion, agreeableness and emotional stability traits. The findings of this study suggest that Higher Education Institutions in Malaysia should target improvements on a specific personality development component pertaining to openness and extroversion personality for business management graduates, and conscientiousness personality for technical graduates as part of the curriculum development strategies of these Higher Education Institutions.
\end{abstract}

Keywords: Personality Traits, Business and Technical Graduates, Importance-performance analysis

\section{Introduction}

Working environments nowadaysrequire people to be more flexible in order to keep up with the continuous changes and developments inside and outside the organisation. This is reflected in personnel selection practices, where more and more emphasis is put on the so-called 'soft' factors and 'generic' competencies such as communication skills and personality features (Spencer \& Spencer, 1993). Presently, work settingsare less structured and productivity is more dependent on individuals' contributions through,for example, interpersonal communication and teamwork. This dependency requires different skills and competencies from people, which are not automatically acquired in the traditional educational context (Boyatzis et al, 1995).These new key qualifications are also called generic competencies (Nijhof, 1998) ; examples of these generic requirements and the importance of personality features for job selection can be found in many job advertisements in magazines and papers.

Human behaviour plays a significant role in maximizing organisational effectiveness, regardless of technological development. Personal characteristics mainly describe and predict human behaviour, not behavioural changes or development. Personal characteristics also indicate different characteristics that can contribute to inferences about behavioural results. More involved persons also feel more

Copyright (C) 2012 Nurazariah Abidin and Salina Daud. This is an open access article distributed under the Creative Commons Attribution License unported 3.0, which permits unrestricted use, distribution, and reproduction in any medium, provided that original work is properly cited. Contact author: Nurazariah Abidin E-mail: azariah@uniten.edu.my 
competent and successful at work, believe that their personal and organisational goals are compatible and tend to attribute positive work outcomes to their internal and personally controllable factors. However, because some people exhibit less variability in their efforts than others, it may be of interest for organisations to identify which employees, whether managers or supervisees, are more prone to variability in their responses. The human personality dimension also might provide a means to determine why an employee appears more or less involved in work. With such information, managers could identify the kinds of personalities that best fit with specific job characteristics and avoid choosing inappropriate staff, as well as coordinate coordinating diverse employee activities to maximize productivity, efficiency and effectiveness.

Hence, the purpose of the study is to evaluate whether there are any differences in the personality traits between Business and Technical Graduates by using an importance-performance analysis.

\section{Literature Review}

\section{Personality Traits}

A personality trait is a consistent and longlasting tendency in behaviour. Various definitions of personality float around in the literature (Pervin, 1990). They differ as to their underlying theoretical assumptions as well as in terms of their usefulness in empirical work. Personality is defined as a rather stable trait, or set of traits, of people that direct their behaviour in different situations (Semeijin et al, 2005). A study by Caspi and Roberts (2001) concludes that personality displays modest continuity from childhood to adulthood, with the consistency in personality increasing with age.

Personality measures that are frequently used in empirical studies into the relationship between personality features and work characteristics are the so-called Big Five personality traits (Gibson et al, 2006; Kreitner \& Kinicki, 2008; Robbins \& Coulter, 2009; Robbins \& Judge, 2009; Tett et al, 1991) or Global Factors Personality (Russell \& Karol, 1994). They comprise openness, conscientiousness, extroversion, agreeableness and emotional stability.

Openness to experience is a tendency to enjoy new intellectual experiences and ideas. Its components include imaginative, curious, unconventional, broadminded and cultured. They have positive disposition towards learning (Salgado, 2002). Openness to experience also suggests an attraction to new ideas, concepts, actions, or feelings (Niehoff, 2006). Persons with higher levels of openness are likely to achieve greater efficiency at work, because they pursue opportunities to learn new perspectives and deal with ambiguous situations. Furthermore, an employee with an open personality should tend to be taskbased constantly searching for new methods to complete his or her work (Stewart \& Nandkeolyar, 2006), which again should strengthen working efficiency.

Conscientiousness is the tendency to show self-discipline, to be dutiful and to strive for achievement and competence. Its components also include self-discipline, consultative, competent, order, dutifulness and thorough. People who are high in this factor have the following features: they are always thorough in decision-making style (Clarke \& Robertson, 2005), they follow rules and regulations (Arthur \& Doverspike, 2001), they are interested in goal targeting and systematic approach, they are always interested in providing adequate cost-benefit analysis and contingency planning (West et al, 1993) and they are less vulnerable to cognitive failures. Low conscientiousness on the other hand, suggests that the employee tries to meet only immediate demands, does not care about prospective results, lacks a sense of goals, mistakenly observes rules (Arthur \& Doverspike, 2001) or standards and performs tasks poorly (Wallace \&Vodanovich, 2003).

Extroversion is to seek simulation and enjoy the company of other people. An extroverted personality tends to be sociable, assertive, gregarious, talkative, and ambitious (Cooper, 2003);so such 
people often use their working environment to represent a key facet of their lives that enables them to meet their aspirations and exhibit their talents (Hurley, 1998). They are sensitive to monotony (Thiffault \& Bergeron, 2003), they are high sensation seekers and have a greater tendency to take risks (Jonah, 1997) and they demonstrate significantly poorer performance on vigilant tasks (Koelega,1992). Highly extroverted employees likely use their stable, coolheaded, optimistic and aggressive manner to react to customers requests, which results in work completion and customer satisfaction.

Agreeableness is a personality dimension that suggests a courteous, flexible, trusting, good-natured, cooperative, forgiving, softhearted and tolerant person (Cooper, 2003). People with this personality are generally easy to get along with (Hough, 1992).They are salient in situations that involve interaction or cooperation with others (Barrick \& Mount, 1991), they are less aggressive, emotionally stable, trustworthy and compliant (Clarke \& Robertson, 2005). Finally, agreeable employees are cooperative and forgiving, tend to follow rules and act courteously to get ahead. High agreeableness therefore has critical implications for understanding service-based productive behaviour and efficiency. In this sense, agreeableness provides a valid predictor of criteria that pertain to customers (Mount \& Ilies, 2006).

Emotional instability is a tendency to experience unpleasant emotions relatively easily. Its components are anxiety, hostility, depression, self-consciousness and impulsiveness. People who are high in this factor have the following features: they are faced with effect of decreasing cognitive and performance capacities (Mathews et al, 1991), they have increasing probability of errors, they are more distracted from the task at hand (Hansen, 1989), they have the tendency to experience greater stress symptoms, they tend to be pre-occupied with their anxieties and worries and there is also evidence that they do not seek active control of the environment (Judge, 1993).

\section{Personalities Among Business Graduates and Technical Graduates}

Henshaw (1991) for instance, has obtained importance rankings of engineer skills and attributes. His study compares employer, employee and faculty rankings of a stated set of skills and concludes that people skills associated with fluent communication, management, practical ability, organisation, teamwork and interpersonal relations are the most highly valued qualities. Evans and Shunk (1992) also include the student body in a very similar study of customer opinion. Both Henshaw (1991) and Evans and Shunk (1992) identify a widening gap between the opinions of practicing engineers and engineering educators which Henshaw (1991) summarises as the employers want more "human" engineering and less technology'. The personal qualities that Newport and Elms (1997) identified in their work can be seen as markers of underlying personality traits. Fitting these results into a Big Five personality model helps us see broader themes and make some interesting predictions. The overall results show that effective engineers are relatively extroverted, open-minded and conscientious. It means that engineers are inclined to be assertive, active and talkative, relish excitement and stimulation, see the big picture, deal well with complexity and work hard to achieve goals. But the downside is that they also have the potential to be bored by the mundane, inclined to the radical, have workaholic tendencies and be seen as pushy and self-centred. Wakelin (1991) criticises engineers for their lack of management skills, illustrating how, although their personalities and education do not predispose them to leadership positions, engineers get things done through others and so by definition are managers. Wilkinson and Lewis (1991) also write about the inability of engineers to fill leadership positions because of the type of person that is attracted to engineering and also because technical education system does not encourage a leadership world-view. 
Barrick and Mount (1991) investigate the relation of the big five personality dimensions to three job performance criteria (job proficiency, training and personnel data) for five occupational groups (professionals, police, managers, sales and skilled/ semi skilled). Result indicates that one dimension of personality, conscientiousness, shows consistent relations with all job performance criteria for all occupational groups.

However, nowadays, the effects of personality traits are being examined across all disciplines. This is because personality is concerned with human beings who are key actors or resources in all spheres of lives. Some of the disciplines where personality traits would certainly have significant influence on performance are the application areas of Information System, Software engineering or Computer Science. Wang and King (2006) explore the characteristics of human factors and their influences in engineering. They present a similar work that applies Real-Time Process Algebra (RPTA) to describe the motivations and attitudes in software engineering (Wang, 2005). Wynekoop and Walz (1998) examine the differences in personality profiles of key IT personnel and find out that there are clear differences. Similar to this is the work of Chilton and Hardgrave (2004), which assesses the behavioural skills (technical and managerial) and determines the relationship between these skills and personality traits.

Houghton (2004) introduces a theoretical framework for understanding the role of personal traits in collaboration in virtual contexts. The work states that individual traits and dyadic complementarities are mediating factors in interpersonal trust and willingness to use new technologies and significantly affect the initiation, duration and productivity of computermediated collaboration. Another interesting work was conducted by Dick and Zarnett (2001) on paired programming and personality traits. The work was carried out to determine whether the members have personality traits that are needed for maximum performance. The work then suggests that the team members in Paired or Extreme programming should be selected based on personality traits that are beneficiary to paired programming approach. Howard (2001) emphasises in his paper the need to check whether software engineers have got the right personality for the job. Sodiya et al (2007) present a technique for personality traits assessment in software engineering. A tool is then developed using Visual Basic to capture personality characteristics of software engineers. Consequently, effective interactions depend largely on personality traits, which is a consistent and longlasting tendency in behaviour. In psychology, five major trait factors (The Big Five Factors) have been generally used to assess personality of people. Chiand Cheng (2009) explains Big Five personality traits and job involvement in an attempt to identify their relationship. Using questionnaire data gathered from 272 Taiwanese plastics industry employees, the study tests five hypotheses using structural equations. Empirical findings show that emotional stability relates negatively to employee job involvement, whereas extroversion, openness, agreeableness and conscientiousness relate positively to it.

\section{Employability of Graduates}

Nowadays, employers are concerned with graduates skills, in which 'graduate skills' are more important in the recruitment process than the graduates academic performances (Harvey, 2000). Basically, employers want a graduate who is equipped with interactive, personal (Harvey, 2000) and generic skills (Hager et al, 2002). This finding has also been supported by Purcell et al (2002) who have revealed that for some employers, a degree may now not represent anything more than a minimum requirement, in addition to other evidence of suitability. According to Candy et al (1994), HEIs have a leadership role in producing graduates with skills for continuing lifelong personal and professional development.

Nicholson and Cushman (2000) find a difference in perception between industry 
participants and educators when ranking attributes for success in the retailing field. They conclude that HEIs need to be careful not to dwell on cognitive skills at the expense of affective skills such as 'leadership' and 'decision making' which may be more important for long term success in the retail field.

Trauth et al (1993) explain that there is an "expectation gap" between industry needs and academic preparation. HEIs must work together to close this gap. Furthermore, HEIs need to place more emphasis on the integration of technologies, applications, data and business functions and less on traditional and formal system development. Meanwhile, Candy et al (1994) find that HEIs have an important role in producing graduates who are not only attuned to the needs of the industry but also equipped with the skills to afford them continuing lifelong personal and professional development.

According to Raybould and Sheedy (2005), for graduates to be attractive to employers, it is important that they are able to show evidence of having the ability to cope with uncertainty, the ability to work under pressure, demonstrate action-planning skills, communication skills, information technology skills, team work, readiness to explore and create opportunities, self confidence, self management skills and a willingness to learn.

\section{Important-Performance Analysis (IPA)}

The important-performance concept is based on multi-attribute models. This technique identifies the performance of an attribute that can be changed without affecting the importance of the attribute (Kitcharoen, 2004). According to Nale et al (2000), a particular application of the technique starts with an identification of the attributes that are relevant to the situations chosen to be investigated. This approach, also known as quadrant analysis, is introduced by Martilla and James (1977). In their study of customer satisfaction, they focus on pinpointing those quality and service elements that; a) are most important to customers and/or are likely to make the strongest contribution to overall customer satisfaction and loyalty; and b) are in need of improvement because customer evaluations of the company's performance of these elements are relatively unfavourable (i.e. customers are dissatisfied and/or perceive that the company's performance is in need of improvement). By using the central tendency measure such as mean, performance scores are ordered and classified into high or low categories, and then by pairing these two sets of rankings, each attribute is placed into one of the four quadrants that are displayed graphically using an importance-performance matrix as in Figure 1 (Eskildsen \& Kristensen, 2006). With little modification, IPA has been applied to a diverse range of contexts including hospital services (Yavas \& Shemwell, 2001), tourism management (Wade \& Eagles, 2003), education (Nale et al, 2000; O'Neill \& Palmer, 2004) and service quality (Ennew et al, 1993; Ford et al, 1999).

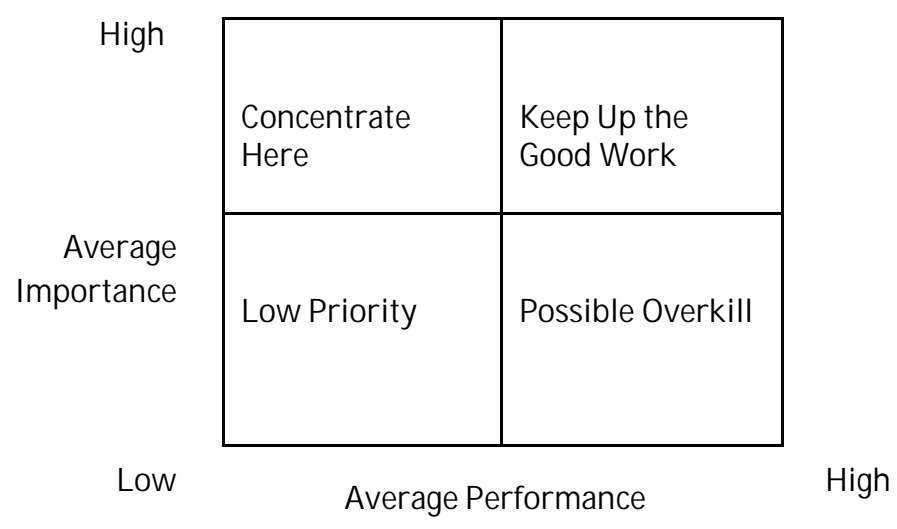

Fig1. Importance-Performance Analysis 
The IPA matrix consists of four quadrants; concentrate here, keep up the good work, low priority and possible overkill (Oliver, 1997). The explanation for each quadrant is as follows:

- Keep up the good work (High importance, high performance). These elements or attributes are assumed to be key drivers of consumer satisfaction/preference, and the management's job is to ensure that the organisation continues to deliver/ perform well in these areas.

- Concentrate here (High importance, low performance). These elements or attributes, also assumed to be key drivers of consumer satisfaction/preference, should be viewed as critical performance shortfalls, and the management's responsibility is to ensure that adequate resources are allocated to improve performance in these areas. These areas are priorities for improvement.

- Low priority (Low importance, low performance). These elements or attributes are assumed to be relatively unimportant, such that poor performance should not be given a great deal of priority or attention by management.

- Possible overkill (Low importance, high performance). These elements or attributes, also assumed to be relatively unimportant, should be viewed as area of performance "overkill", and management may want to redirect resources from these elements to high-priority areas in need of improved performance.

\section{Material and Methods}

The study is carried out in two phases. Phase 1 involves a focus group session of 10 members intended to extract information from managers through a brainstorming session. This session focuses on the growing concern among employers about the relevance of the HEI curriculum in the face of developments in the real world today. In Phase 2, the dominant theme(s) emerging from the focus group study are used to establish a questionnaire appropriate for the study involving industries from across the board.

Graduates personality attributes are evaluated based on the importantperformance paradigm introduced by Martilla and James (1977). The personality dimensions are divided into five parts, also known as big five personality which includes conscientiousness, agreeableness, emotional stability, openness and extroversion.

The graduates in the study are students from business and technical background. The database used to establish the sampling frame is obtained from the records of the HEI's Alumni Centre (1065 companies) and companies listed in the Malaysian Top Corporation Directory 2007-2008 for business and technical graduates respectively.

The questionnaire is divided into two parts. Part A focuses on demographic profiles of the respondents, while Part B measures the managers' perceptions of important characteristics and the performance of the graduates. The questionnaires are distributed to the managers of the selected companies. This exercise enables the examination of the gap between the perceptions of managers of the important personality dimensions of graduates and their actual performance in the work place.

\section{Results and Discussion}

\section{Demographic Profile}

For business graduates, 479 completed questionnaires were received representing a $45 \%$ response rate. The majority of the graduates are attached to service companies (64\%) followed by manufacturing and construction industry with $19 \%$ and $8 \%$ respectively. Most of these graduates are employed by companies located in the central region of Peninsular Malaysia (54\%). Half of the respondents of the survey are in top 
management positions (52\%) and the majority of their executive staff are degree holders (40\%).

For technical graduates, 478 completed questionnaires were received representing a $48 \%$ response rate. The majority of the graduates are attached to manufacturing companies (53\%) followed by service and construction industries with $25 \%$ and $13 \%$ respectively. Most of these graduates are employed by companies located in the central region of Peninsular Malaysia (50\%). Approximately two third of the respondents in the survey are in middle management positions (64\%) and the majority of their executive staff are degree holders (45\%). Half of the respondents are Malay (57\%) and $65 \%$ of them are male respondents.

\section{Validity and Reliability of the Instruments}

The survey questions used for this study conform to the entire validity requirement. Content validity has been verified during focus group discussion. The feedback and emergent issues raised by the focus group were translated into scale items in the questionnaire. The focus group have raised a few major issues regarding graduates personalities. The development of the graduates personalities dimensions is based on focus groups suggestion and literature review. All necessary dimensions for graduatespersonalities attributes are included. These dimensions are also confirmed as having content validity. Factor analysis was used to establish construct validity for all the scale items of the dimensions employed in this study (Kerlinger \& Lee, 2000). All of the items in the dimensions are factor-analysed and loaded in accordance with prior theoretical expectations. The results of the analysis of data revealed satisfactory output for further analysis.

The reliability of the data was verified using Cronbach alpha, where the closer the Cronbach alpha is to 1 , the higher the internal consistency reliability (Sekaran, 2000). The alpha coefficients for this study are all above 0.70 and were considered to be reliable (Hair et al, 2006; Nunnally, 1978). Table 1and Table 2 present the Cronbach alpha coefficient for each variable for business and technical graduates respectively.

Table 1: Reliability Statistics for Importance and Actual Performance Scale (Business Graduates)

\begin{tabular}{|l|c|c|c|}
\hline \multicolumn{1}{|c|}{ Personality Dimensions } & Importance & Actual Performance & No. of item \\
\hline Conscientiousness & 0.914 & 0.932 & 5 \\
\hline Agreeableness & 0.822 & 0.902 & 4 \\
\hline Emotional stability & 0.879 & 0.914 & 4 \\
\hline Openness & 0.890 & 0.934 & 5 \\
\hline Extroversion & 0.867 & 0.914 & 4 \\
\hline
\end{tabular}

Table 2: Reliability Statistics for Importance and Actual Performance Scale (Technical Graduates)

\begin{tabular}{|l|c|c|c|}
\hline \multicolumn{1}{|c|}{ Personality Dimensions } & Importance & Actual Performance & No. of item \\
\hline Conscientiousness & 0.919 & 0.926 & 5 \\
\hline Agreeableness & 0.888 & 0.907 & 4 \\
\hline Emotional stability & 0.919 & 0.918 & 4 \\
\hline Openness & 0.914 & 0.925 & 5 \\
\hline Extroversion & 0.924 & 0.921 & 4 \\
\hline
\end{tabular}


In all cases, it is found that the reliability scores for performance are greater than the reliability scores for expectations indicating that respondents find it relatively easier to assess the performance of graduates than to estimate their own expectations of the graduates under their supervision.

\section{Importance-performance analysis}

A summary of managers' importanceperformance means for 5 scale items is presented in Table 3 and Table 4 for business and technical graduates respectively. The negative gap values between importance-performance indicate that the graduates performances have not met the managers' perceptions of the importance attributes that should be possessed by these graduates. In other words, graduates from the HEIs were under performing significantly in all attributes rated important by the supervisors and managers.

\section{Table 3: Summary of Means Importance and Actual Performance (Business Graduates)}

\begin{tabular}{|l|c|c|c|}
\hline \multicolumn{1}{|c|}{ Personality Dimensions } & Importance & Performance & Gap (P-I) \\
\hline Conscientiousness & 6.266 & 5.267 & -0.999 \\
\hline Agreeableness & 6.154 & 5.155 & -0.999 \\
\hline Emotional stability & 6.285 & 5.284 & -1.001 \\
\hline Openness & 6.277 & 5.245 & -1.032 \\
\hline Extroversion & 6.312 & 5.210 & -1.102 \\
\hline Overall & 6.263 & 5.250 & \\
\hline
\end{tabular}

Note: (P-I) value is significant at $\mathrm{p}<0.05$

Table 4:Summary of Means Importance and Actual Performance (Technical Graduates)

\begin{tabular}{|l|c|c|c|}
\hline \multicolumn{1}{|c|}{ Personality Dimensions } & Importance & Performance & Gap (P-I) \\
\hline Conscientiousness & 6.427 & 5.638 & -0.789 \\
\hline Agreeableness & 6.343 & 5.607 & -0.736 \\
\hline Emotional stability & 6.449 & 5.643 & -0.806 \\
\hline Openness & 6.423 & 5.656 & -0.767 \\
\hline Extroversion & 6.464 & 5.645 & -0.819 \\
\hline Overall & 6.421 & 5.638 & \\
\hline
\end{tabular}

Note: (P-I) value is significant at $\mathrm{p}<0.05$

The importance-performance map is presented in Figure 2 and 3 for business and technical graduates respectively. The data used to construct the importance- performance grid were the overall means of importance and performance for all scale items 
9 Communications of the IBIMA

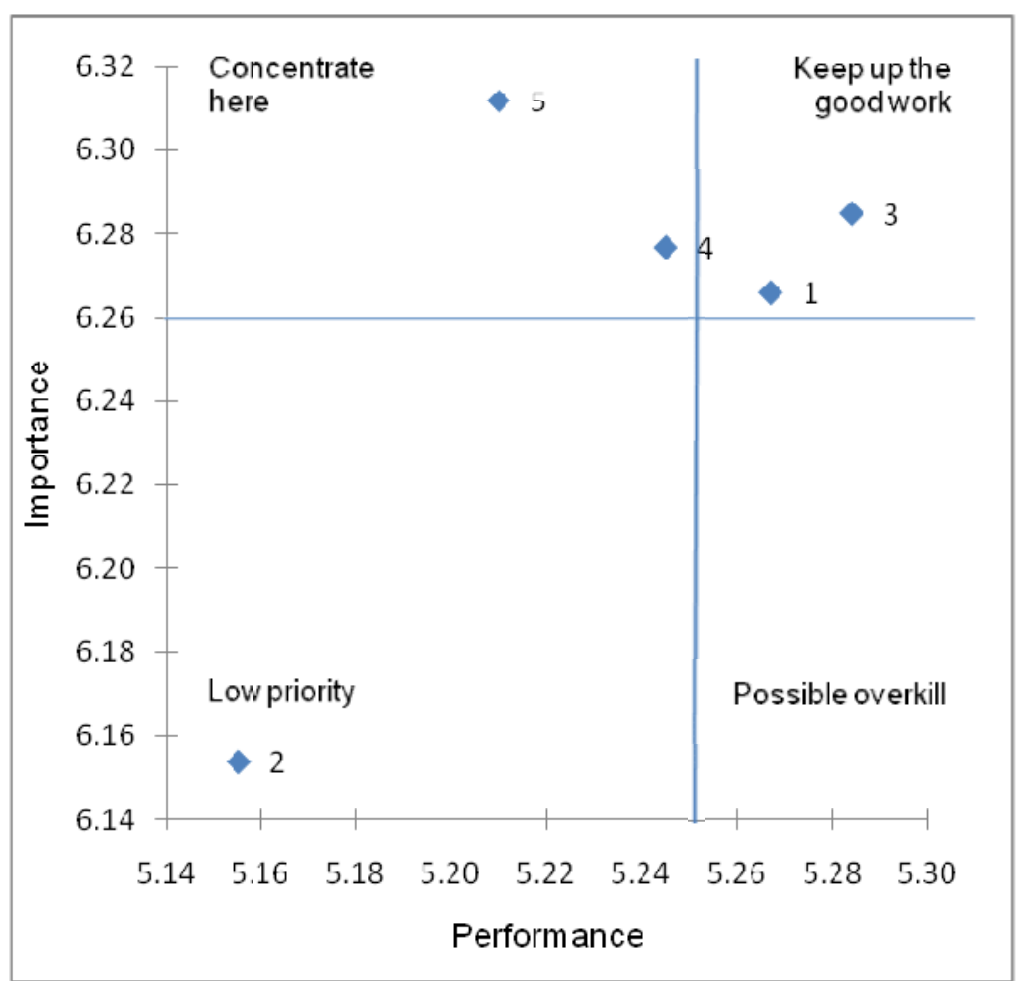

Note: 1--conscientiousness, 2-agreeableness, 3-emotional stability, 4-openness, 5-extroversion

Fig2. Importance-Performance Map (Business Graduates)

Two items fall into the "concentrate here" quadrants (high importance/low performance) which are openness personality and extroversion personality. HEIs need to take immediate action on these business graduates attributes, while the other/ another two items are located in the quadrant "keep up the good work" (high importance/high performance), which are conscientiousness personality and emotional stability personality. These two attributes are the strength attributes possessed by business graduates from the HEI in the sample, which means that business graduates produced by this institution possess good emotional stability and conscientious personalities. Only one attribute falls in the "low priority" quadrant and itis in relation to agreeableness personality. This indicates that this attribute does not require immediate resource allocation as they are performing at the level appropriate to the importance attached to them at the present time. However, the HEI should hold in reserve resources to cope with a possible change of importance attached to them due to future changes in the employment environment. 


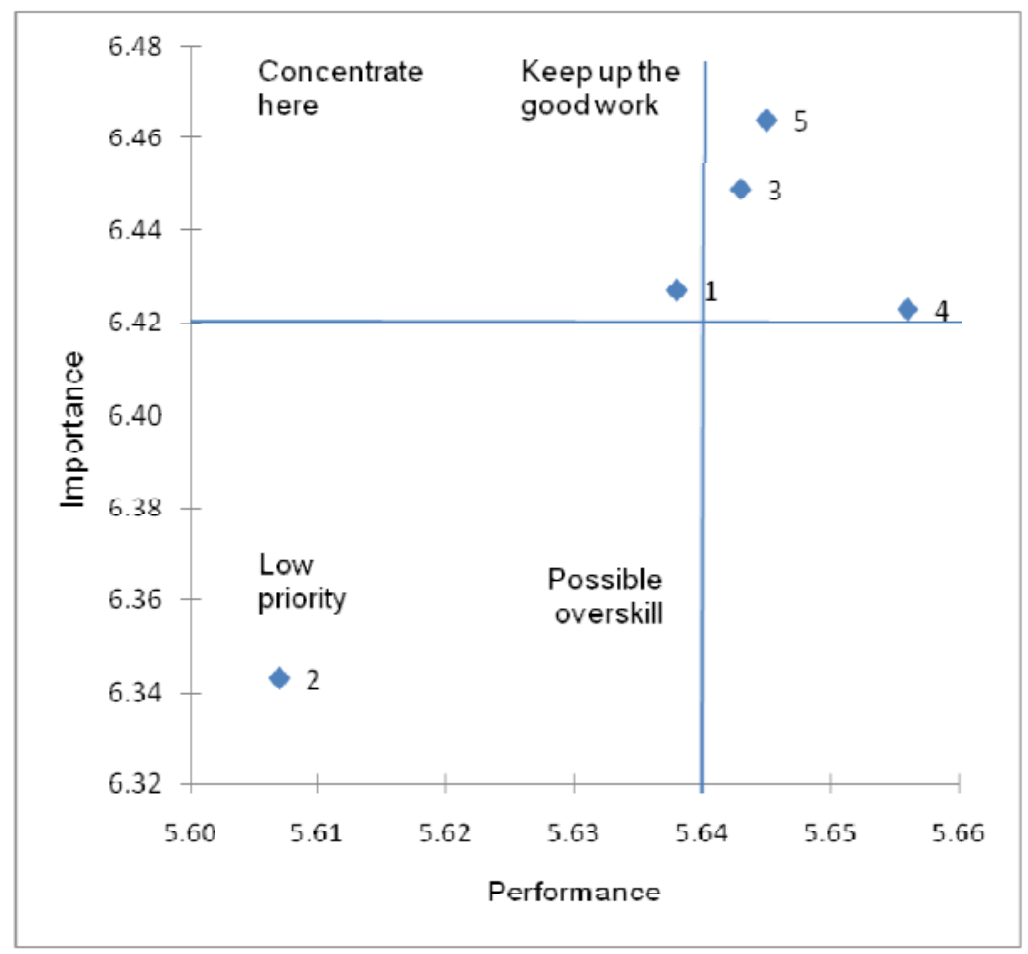

Note: 1--conscientiousness, 2-agreeableness, 3-emotional stability, 4-openness, 5-extroversion

\section{Fig 3.Importance-Performance Map (Technical Graduates)}

Figure 2 presents the managers' importance-performance map for technical graduates. One attribute falls into the "concentrate here" quadrants (high importance/low performance); that is the conscientiousness personality. This indicates that HEIsneed to take immediate action on these technical graduates attributes. On the other hand, three attributes we a located in the quadrant "keep up the good work" (high importance/high performance), and these attributes include emotional stability personality, openness personality and extroversionpersonality. For this, HEIs only need to maintain their current allocation of resources in developing these factors in the curriculum design of the HEIs. These three attributes are the strength attributes possessed by technical graduates, which means that technical graduates produced by HEIs possess good personalities, namely extroversion, emotional stabilityand openness personality. Only one technical graduate attribute falls in the "low priority" quadrant is in relation toagreeableness personality. This indicates that this attribute does not require immediate resource allocation as it is performing at the level appropriate to the importance attached to it at the present time. However, the HEIs should hold in reserve resources to cope with a possible change of importance attached to it due to changes in the employment environment in the future.

From the above discussion, it shows that HEIs need to enhance curriculum design which focuses more on openness and extroversion personality and conscientiousness personality for business and technical graduates respectively.

\section{Conclusion and Future Research}

This study provides evidence of the usefulness of the IPA in designing 
curriculum development strategies for HEIs in Malaysia. The outcome of the analysis provides impetus for enhancing the quality of the higher education curriculum and making it relevant to the needs of the market and industries. The study highlights the practicality of the IPA as a means to assessing and directing continuous curriculum development efforts within the higher education sector. The use of the IPA in evaluating managers' perceptions of graduates personality attributes can identify how graduates are performing, identify specific problem areas and help target corresponding improvement efforts.

The study reveals the factors relevant to the managers' perceptions of the graduates and their satisfaction level with the performance of the HEI's graduates. The results of this study indicate that managers attach different weightings to different aspects of the graduates performance and, therefore, curriculum development efforts should be directed towards attributes that are expected from the graduates. This will allow for corrective actions which can then be taken to improve perceived problem areas. The findings of this study suggest that the HEIs in Malaysia should target improvements on a specific personality development component pertaining to openness and extroversion personality for business management curriculum design and conscientiousnesspersonality for technical curriculum design as part of the curriculum development strategies of these HEIs.

Clearly, these HEIs should undertake extensive employer research in order to identify those factors expected in their evaluations of graduates performance. Consequently, this information can assist in decision making on a range of fronts, including facilities development, positioning attributes, curriculum development and the delivery of the core curriculum in Malaysia in an effort to produce a competitive workforce internationally.

It should be noted that this is a case study of graduates from HEIs in Malaysia. Future research could seek to establish whether a consistent pattern is observable across graduates from all other HEIs in different categories of industries and the different levels of managers expectations among other countries within the South East Asian region. It also should be noted that the quantitative analysis used does not explain why the observed ratings occurred. A supplementary exploratory study is required to address this concern. However, it must be remembered that the managers expectations and performance ratings for specific attributes change over time due to changes in the macro environment.

\section{References}

Arthur, W. \& Doverspike, D. (2001)."Predicting Motor Vehicle Crash Involvement from a Personality Measure and a Driving Knowledge Test," Journal of Prevention and Intervention in the Community, vol. 22, pp. 35 - 42.

Barrick, M. R. \& Mount, M. K. (1991)."The Big Five Personality Dimensions and Job Performance: A Meta Analysis," Journal of Personnel Psychology, vol.44, pp. 1-26.

Boyatzis, R. E., Cowen, S. S. \& Kolb, D. A. (1995). 'Innovation in Professional Education: Steps on a Journey from Teaching to Learning. The Story of Change and Invention at the Weatherhead School of Management,' San Francisco: Jossey-Bass Publishers.

Candy, P.C., Crebert, R.G. \& O’Leary, J. (1994). 'Developing Lifelong through Undergraduate Education,' National Board of Employment, Education and Training Commissioned, Canberra: AGPS, Report No. 28.

Caspi, A., \& Roberts, B. W. (2001). "Personality Development across the Life Course: The Argument for Change and Continuity," Psychological Inquiry, vol. 12, pp.

49-66.

Chi S.L. \& Cheng W. L. (2009)."An Empirical Study of Employee Job Involvement and Personality Traits: The Case of Taiwan," Int. 
Journal of Economics and Management, vol. 3, no. 1, pp. 22 - 36

Chilton, M. A. \& Hardgrave, B. C. (2004). "Assessing Information Technology Personnel: Toward a Behavioral Rating Scale," The DATABASE for Advances in Information Systems, vol. 35, no. 3, pp. 88104.

Clarke, S. \& Robertson, I.T. (2005). "A MetaAnalytic Review of the Big Five Personality Factors and Accident Involvement in Occupational and Non Occupational settings," Journal of Occupational and Organizational Psychology, vol. 78, pp. 355 $-376$

Cooper, D. (2003).'Psychology, Risk and Safety,' Professional Safety, vol. 48,pp. 3946.

Dick, A. J. \& Zarnett, B. (2001)."Paired Programming \& Personality Traits," Third International Conference on XP and Agile Processes in Software Engineering, May 26-29, Alghero, Sardinia, Italy

Ennew, C., Reed, G. \& Binks, M. (1993). "Importance-Performance Analysis and the Measurement of Service Quality," European Journal of Marketing, vol. 27, no. 2, pp. 5970 .

Eskildsen, J. K. \& Kristensen, K. (2006). "Enhancing Importance-Performance Analysis," International Journal of Productivity and Performance Management, vol. 55, no. 1, pp. 40-60.

Evans, D. L. \& Shunk, D. L. (1992). 'Attributes for the Baccalaureate Engineer: What are the Desires of Industry? in T. V. Duggan (Ed),' Proc. 3rd World Conference on Engineering Education Vol.1: International Quality and Environmental Issues, Computational Mechanics Publications, Southampton, Boston.

Ford, J. B., Joseph, M. \& Joseph, B. (1999). "Importance- Performance Analysis as a Strategic Tool for Service Marketers: The Case of Service Quality Perceptions of Business Students in New Zealand and the
USA," The Journal of Services Marketing, vol. 13 , no. 2, pp. 71-186.

Gibson, J. L., Ivancevich, J. M., Donnelly, J. H. \& Konopaske, R. (2006). Organizations: Behavior, Structure and Processes,12th Edition. Boston, MA: McGraw-Hill.

Hair, J. F., Black, W. C., Babin, B. J., Anderson, R. E. \&Tatham, R. L. (2006). Multivariate Data Analysis,Sixth Edition, Upper Saddle River, New Jersey: Pearson Education International.

Hager, P., Holland, S. \& Beckett, D. (2002). "Enhancing the Learning and Employability of Graduates: The Role of Generic Skills," Business/Higher Education Round Table, Retrieve from http:/ / www.bhet.com

Hansen, C. P. (1989). "A Casual Model of the Relationship among Accidents, Biodata, Personality and Cognitive Factors," Journal of Applied Psychology,vol. 74, pp. 81-90.

Harvey, L. (2000). "New Realities: The Relationship between Higher Education and Employment," Tertiary Education and Management, vol. 6, pp. 3-17.

Henshaw, R. (1991). 'Desirable Attributes for Professional Engineers, in John B. Agnew and Caryl Cresswell (eds.),' Proc. Australian Association for Engineering Education: 3rd Annual Convention and Conference, University of Adelaide.

Hough, I. M. (1992). "The Big Five Personality Variables - Construct Confusion: Description Versus Prediction," Journal of Human Performance,vol. 5, pp. 139-155.

Houghton, G. B. (2004). "Interpersonal Traits, Complementarity, and Trust in Virtual Collaboration,"Journal of Management Information System, Vol. 20 No. 4, pp. 115 - 137

Howard, A. (2001). "On Site Software Engineering Project Management," Communications of the ACM, Vol. 44, no. 5, pp 23-24 
Hurley, R. F. (1998). "A Customer Service Behavior in Retail Settings: A study of the Effect of Service Provider Personality," Journal of the Academy of Marketing Sciences, vol. 26, pp. 115 - 227.

Jonah, B. A. (1997). 'Sensation Seeking and Risky Driving,' In T. Rothengatter \& E. Carbonell Vaya (Eds.), Traffic and Transport Psychology: Theory and Application, Oxford: Pergamon.

Judge, T. A. (1993). "Does Affective Disposition Moderate the Relationship between Job Satisfaction and Voluntary Turnover ?," Journal of Applied Psychology, vol. 78, pp. 395-401.

Kerlinger, F. N. \& Lee, H. B. (2000). Foundations of Behavioural Research, 4th edition, New York, Wadsworth: Thomson Learning.

Kitcharoen, K. (2004). "The ImportancePerformance Analysis of Service Quality in Administrative Departments of Private Universities in Thailand," ABAC Journal, vol. 24. no. 3, pp. 20-46.

Koelega, H. S. (1992). 'Extraversion and Vigilance: 30 years of Inconsistencies,' Psychological Bulletin, vol. 112, pp. 239258.

Kreitner, R. \& Kinicki, A. (2008). Organizational Behaviour, 8th Edition, Boston, MA: McGraw-Hill.

Martilla, J. A. \& James, J.C. (1977). "Importance-Performance Analysis," Journal of Marketing, vol. 41, no. 1, pp. 7799.

Mathews, G., Dorn, L. \& Glendon A. I. (1991). "Personality Correlates of Driver Stress "Journal of Personality and Individual Differences, vol. 12, pp. 535-549.

Mount, M. , Ilies, R. \& Johnson, E. (2006). "Relationship of Personality Traits and Counterproductive Work Behaviors: The Mediating Effects of Job Satisfaction," Personnel Psychology, vol. 59, pp. 591 622.
Nale, R. D., Rauch, D. A., Wathen, S. A. \& Barr, P. B. (2000). "An Exploratory Look at the Use of Importance-Performance Analysis as a Curricular Assessment Tool in a School of Business," Journal of Workplace Learning: Employee Counselling Today, vol. 12, no. 4, pp. 139-145.

Newport, C. L. \& Elms, D. G. (1997). "Effective Engineers," International Journal of Engineering Education, vol. 13, no. 5, pp. 325-332.

Nicholson, A. \& Cushman, L. (2000). "Developing Successful Employees: Perceptions of Industry Leaders and Academicians," Education and Training, vol. 42, no. 6, pp. 366-371.

Niehoff, B.P. (2006). "Personality Predictors of Participation as a Mentor," Career Development International, vol. 11, pp. 321 - 333.

Nijhof, W. J. (1998). "Qualifying for the Future". In W. J. Nijhof \& J. N. Streumer (Eds.), Key Qualifications in Work and Education, Dordrecht: Kluwer Academic Publishers.

Ninth Malaysian Plan 2006-2010, Report Economic Planning Unit. Malaysia

Nunnally, J. C. (1978). Psychometric Theory, 2nd Edition, New York: Mc-Graw Hill.

O'Neill, M. \& Palmer, A. (2004). "Importance-Performance Analysis: A Useful tool for Directing Continuous Quality Improvement in higher Education," Quality Assurance in Education, vol. 12, no. 1, pp. 39-52.

Oliver, R.L. (1997). 'Satisfaction: A Behavioral Perspective on the Consumer,' Boston, MA: McGraw-Hill,

Pervin, L. A. (1990). Personality: Theory and Research, 5th Edition, London: John Wiley and Sons.

Purcell, K., Morley, M. \& Rowley, G. (2002). "Employers in the New Graduate Labour Market: Recruiting from a Wder Spectrum 
of Graduate," Employment Studies Research Unit, London: CIHE-ESRU.

Raybould \& Sheedy (2005). "Are Graduates Equipped with the Right Skills in the Employability Stakes?" Industrial and Commercial Training, vol. 37, no. 5, pp. 259263.

Robbins, S. P. \& Coulter, M. (2009). "Management," 10th Edition, Upper SaddleRiver, New Jersey: Pearson Education Inc.

Robbins, S. P. \& Judge, T. A. (2009). "Organizational Behaviour," 13th Edition, Upper Saddle-River, New Jersey: Pearson Education Inc.

Russell, M.T., \& Karol, D. (1994). '16PF Fifth Edition Administrator's manual Champaign,' IL: Institute for Personality \& Ability Testing.

Salgado, J. F. (2002). "The Big Five Personality Dimensions and Counterproductive Behaviors," International Journal of Selection and Assessment, vol. 10, pp. 117-125.

Sekaran, U. (2000). 'Research Methods for Business: A Skill-building Approach,' New York: John Wiley and Sons, Incorporation.

Semeij, J., Boone, C., van der Velden, R.\& van Witteloostuijn, A. (2005). "Graduates Personality Characteristics and Labor Market Entry an Empirical Study among Dutch Economics Graduates," Journal Economics of Education Review, vol. 24, pp. 67-83.

Sodiya, A.S.,Longe ,H. O. D.,Onashoga, S. A.,Awodele,O. (2007). "An Improved Assessment of Personality Traits in Software Engineering," Interdisciplinary Journal of Information, Knowledge, and Management,vol. 2, pp. 164-177.

Spencer, L. M. \& Spencer, S. M. (1993). Competence at Work: Models for Superior Performance, New York: John Wiley and Sons.

Stewart, G.L. \& Nandkeolyar, A.K. (2006). "Adaptation and Intraindividual Variation in Sales Outcomes: Exploring the Interactive Effects of Personality and Environmental Opportunity," Personnel Psychology, vol. 59, pp. 307 - 332.

Tett, R. P., Jackson, D. N., \& Othstein, M. (1991). "Personality Measures as Predictors of Job Performance: A MetaAnalytic Review," Personnel Psychology, vol. 44, pp. 703-742.

Thiffault, P. \& Bergeron, J. (2003). "Fatigue and Individual Differences in Monotonous Stimulated Driving," Journal of Personality and Individual Differences,vol. 34, pp. 159176.

Trauth, E., Farwell, D. \& Lee, D. (1993). "The IS Expectation Gap: Industry Expectations Versus Academic Preparation," MIS Quarterly, vol. 17, no. 3, pp. 293-307.

Wade, D. \& Eagles, P. (2003)." The Use of Importance-performance Analysis and Market Segmentation for Tourism Management in Parks and Protected Areas: An Application to Tanzania's National Parks," Journal of Ecotourism, vol. 2, no. 3, pp. 196-212.

Wakelin B.(1991). 'The Education of Engineers Fit for Management?,' In P. T. Gough (Ed), Engineering Education, the Way Forward: Proc. AEESEAP Triennial Conference, University of Canterbury, Christchurch.

Wallace, J.C. \& Vodanovich, S. J. (2003). "Workplace Safety Performance: Conscientiousness, Cognitive Failure, and their Interaction," Journal of Occupational Health Psychology, vol.8, pp. 316 - 327.

Wang, Y. (2005). 'On Cognitive Process of Human Perception,' Cognitive Informatics. Proceedings of the 4th IEEE International Conference, (ICCI'05), IEEE CS Press, Irvine, California, USA, August.

Wang, Y. \& King, G. (2006). 'Software Engineering Processes: Principles and Applications,' USA: CRC Press Series. 
West, R. J., Elander, J. \& French, D. (1993).

"Mild Social Deviance, Type-A Behaviour Pattern and Decision Making Style as Predicators of Self-Reported Driving Style and Traffic Accident Risk," British Journal of Psychology, vol. 84, pp. 207-219.

Wilkinson R. W. \& Lewis P. (1991). 'Engineering Education: A Preparation for Leadership?,' In P. T. Gough (Ed.), Engineering Education, the Way Forward: Proc. AEESEAP Triennial Conference, University of Canterbury, Christchurch.

Wynekoop, J. L. \& Walz, D. B. (1998). "Revisiting the Perennial Question: Are IS People Different?," The Database for Advances in Information Systems,vol. 29, no. 2, pp.62-72

Yavas, U. \& Shemwell, D. (2001). 'Managing Performance for Improved Productivity: The importance of Performance Management Analysis,' International Journal of Health Care Quality Assurance, vol. 14, no. 3, pp. 104-110. 